\title{
Synthesis and Initial Evaluation of a Novel Fluorophore for Selective FMDV 3C Protease Detection
}

\author{
Samerah Malik, Alex Sinclair, Ali Ryan $『$ and Adam Le Gresley* \\ Chemical and Pharmaceutical Sciences, SEC Faculty, Kingston University, Kingston-upon-Thames, \\ London KT1 2EE, UK; k0613436@kingston.ac.uk (S.M.); alegresley1@hotmail.com (A.S.); \\ ali.ryan@northumbria.ac.uk (A.R.) \\ * Correspondence: a.legresley@kingston.ac.uk; Tel.: +44-(0)208-4177432
}

Received: 11 July 2020; Accepted: 4 August 2020; Published: 7 August 2020

\begin{abstract}
The development and evaluation of a Boc-AL(Boc)Q(Trt)-AMC fluorophore to detect $3 \mathrm{C}$ Protease, produced by Foot and Mouth Disease Virus (FMDV) is reported, with a view to a potential use as a rapid screen for FMDV infected livestock The peptide-linked conjugate fluorophore is evaluated in vitro for sensitivity, specificity, stability and rapidity and shows statistically significant increases in fluorescence when exposed to physiologically relevant concentrations of $3 C$ Protease and selectivity when compared with other common proteases likely to be located, typically in the absence of FMDV. The stability of deprotected Boc-AL(Boc)Q(Trt)-AMC is reported as a limitation of this probe.
\end{abstract}

Keywords: FMDV; 3C protease; fluorescence; veterinary testing

\section{Introduction}

Foot and Mouth Disease Virus (FMDV) is an extremely contagious pathogen and an outbreak caused by this virus can cause economic devastation, food insecurity, poverty and restrict food trade [1]. As a result, strategies to control, manage and prevent the spread of infection via early detection are a requirement. The World Organisation for Animal Health has published a manual of diagnostic tests and vaccines that defines FMDV diagnosis tests and states diagnosis can be achieved via virus isolation, detecting nucleic acid, viral antigen, virus specific or viral non-structural protein (NSP) antibodies irrespective of the vaccination status of the animal [2]. A number of lab-based diagnostic techniques are listed that can be used to detect viral pathogens and give a clinical diagnosis. Over the years, a range of these molecular biological tests have been modified to specifically detect FMDV: complement fixation test (CFT), virus neutralisation (VN), enzyme linked immunosorbent assay (ELISA) and polymerase chain reaction (PCR) [3-5].

Often, the delay in diagnosis is caused by the need of the infected sample to be transported to a high containment laboratory with certification to work with FMDV and requires skilled personnel using specialist equipment. Other limitations for consideration are: the need of the sample originating from a specific source to comply with the diagnostic technique-epithelial, blood and sputum, and the expenses involved in portable systems and the stability of reagents [6].

To date three main pen-side diagnostic technologies that have been reported include:

- Nucleic acid detection using RT-PCR;

- Antigen detection using different formats of lateral flow devices (LFD);

- LFD detection after isothermal amplification using primers of certain regions of the FMDV genome. 
PCR is considered a powerful and sensitive technique, hence the development of portable PCR systems for FMDV detection; however, field testing made the limitations of the system apparent as it requires a precision thermo-cycling step that is carried out using expensive, fragile instrumentation that requires a vigorous decontamination protocol of the instrument to be followed after each site use [7]. In order to reduce the costs associated with the necessary cycling at different reaction temperatures for the portable PCR system, isothermal amplification strategies were explored in viral diagnostics. In 2000, Notomi et al. developed a molecular technique based on loop mediated isothermal amplification (LAMP), a technique widely used to detect viruses [8].

LFDs are rapid, deployable detection platforms; however, antibody/antigen based LFDs offer equivalent or less diagnostic sensitivity when compared to Ag-ELISA for certain serotypes, and can only be applied to the acute phase of FMD where samples collected contain high amounts of viral particles from vesicular or epithelial samples. These application requirements render the device useless in the incubation period and in the absence of obvious clinical signs, whereas isothermal-based assays allow for the evaluation of samples from various sample types: epithelial suspensions, serum and oesophageal-pharyngeal fluids $[9,10]$.

A further complication with pen-side diagnostic kits is the need to maintain the integrity of the reagents, such as enzymes being utilized. To address this, methods have been developed to lyophilise reagents, making them stable under less optimal/harsher conditions, as seen in many areas affected by FMD. In 2015, Howson et al. reported the validity of the use of lyophilised reagents in field settings of East Africa (FMD endemic location) on RT-LAMP and RT-PCR assays, the group have reported no adverse effects on the performance of the assays [11]. Despite these advances, there is still scope for a rapid, point-of-decision-making test, which can be stored and deployed in the field easily [12]. In this

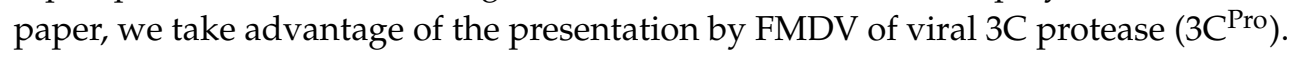

$3 \mathrm{C}^{\text {pro }}$ is a chymotrypsin-like cysteine protease. It is 213 amino acids long with a molecular weight of around $23 \mathrm{kDa}$. The enzyme's sequence is highly conserved, $\sim 82-85 \%$ identical over all known serotypes without any cellular equivalents in host cells, and it is therefore a suitable target for our FMDV detection $[13,14]$. The enzyme cleaves the viral polypeptide chain and is vital for further processing of the sequence as it recognises and cleaves 10 of the 13 polypeptide junctions. It also interacts with a wide range of host proteins involved in the host's immunity (Table 1), thereby successfully suppressing cellular immune responses. This shows that $3 C^{\text {pro }}$ plays a critical role in viral pathogenesis.

Table 1. Host-cell proteins cleaved by $3 \mathrm{C}^{\mathrm{pro}}$.

\begin{tabular}{cc}
\hline Host Cell Protein & Function of Protein \\
\hline eIF4G, eIF4A1 [15] & Eukaryotic translation initiation factors \\
H3 [16] & Histone \\
NEMO [17] & NF-kappa-B an essential modulator for IFN $\alpha / \beta$ responses \\
Sam68 [18] & Sequence-specific RNA binding protein that regulates alternative splicing \\
\hline
\end{tabular}

$3 C^{\text {pro }}$ cleaves a large number of amino acid pairs during primary and secondary processing. These include: $\mathrm{E} / \mathrm{G}, \mathrm{E} / \mathrm{T}, \mathrm{Q} / \mathrm{K}, \mathrm{Q} / \mathrm{G}, \mathrm{Q} / \mathrm{T}$ and $\mathrm{Q} / \mathrm{M}$, but the main sequence recognized and cleaved by $3 \mathrm{C}^{\text {Pro }}$ is $\mathrm{H}_{2} \mathrm{~N}$-Ala-Lys-Gln-OH.

The resolution of the atomic structure of $3 C^{\text {pro }}$ FMDV revealed important structural features. The enzyme adopts a chymotrypsin like fold, as observed in most serine proteases with a conserved catalytic triad made up of Ser-His-Asp [19,20]. In an elegant example of this, Leatherbarrow et al. probed various oligopeptides as part of a DABCYL-EDANS FRET pair for use as a continuous $3 C^{\text {Pro }}$ monitoring fluorophore [21]. Despite this, there has been little done to establish the selectivity of these fluorophores for $3 \mathrm{C}^{\mathrm{Pro}}$ and there remains scope for the generation of new fluorogenic assays for use as rapid affordable field tests for FMDV [22]. 


\section{Results}

\subsection{Synthesis}

The $\mathrm{H}_{2} \mathrm{~N}$-Ala-Lys-Gln-OH tripeptide was coupled to AMC using peptide coupling conditions described in the Section 4. Initially, the synthesis of Boc-AK(Z)Q-AMC 1 proved capricious in terms of purification. As a result, a trityl protecting group was introduced to afford Boc-AL(Boc)Q(Trt)-AMC 2.

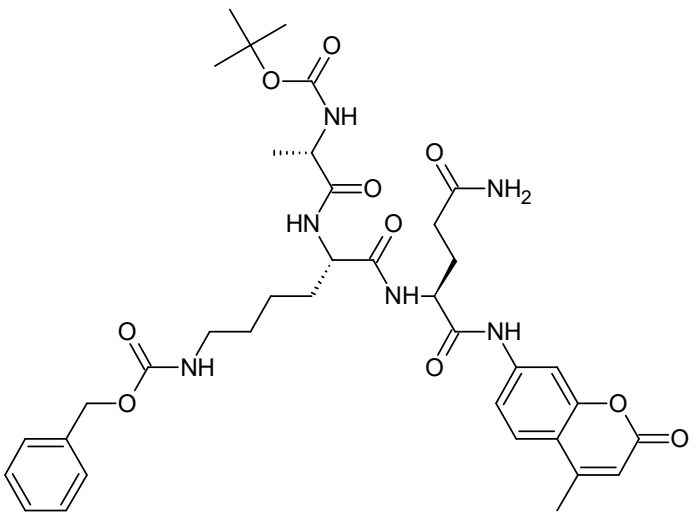

1 Boc-AK $(Z) Q-A M C$

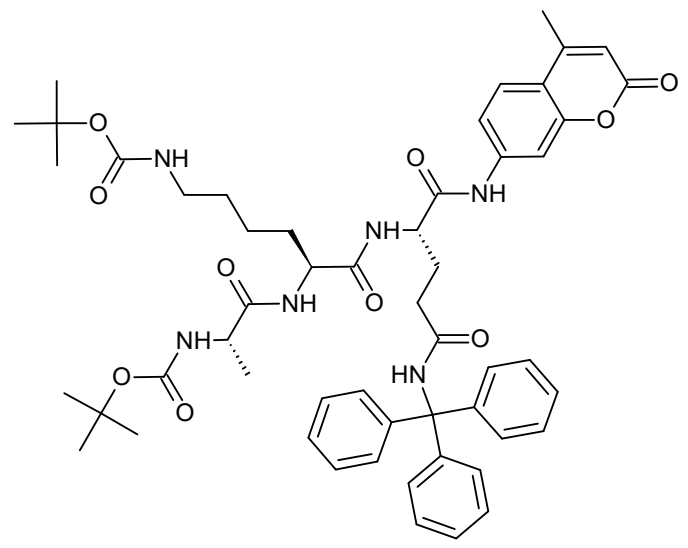

2 Boc-AK(Boc)Q(Trt)-AMC

Introduction of the trityl group on to the glutamine's side chain increased the stability and solubility of the compound, improving the handling of the compound during the purification process. However, the overall yield was still very low (Table 2), due to the reliance of the final coupling on a coupling reagent, a problem faced throughout the project.

Table 2. Fluorogenic substrates successfully isolated and their overall percentage yields.

\begin{tabular}{cc}
\hline Fluorogenic Substrate Successfully Isolated & Overall Yield \\
\hline Boc AL(Z)QAMC, 1 & $0.4 \%$ \\
Boc AL(Boc)Q(Trt)AMC, 2 & $15.7 \%$ \\
\hline
\end{tabular}

Compounds 1 and 2 require acid treatment to deprotect the substrate ready for biochemical testing. In our hands, the unprotected tripeptide sequence was unstable; therefore, the ideal situation for the biochemical testing of this compound was to deprotect it in the presence of the target enzyme, to minimise any premature decomposition.

$3 C^{\text {pro }}$ was kindly provided by the Pirbright Institute in Surrey. Details of the mutations in the supplied $3 \mathrm{C}^{\text {pro }}$ strain are $\mathrm{C} 95 \mathrm{~K}$ and $\mathrm{C} 142 \mathrm{~A}$., which are reported to improve solubility and proteolytic activity, respectively [23]. DSF was used to see if in situ trityl/Boc deprotection could be undertaken without detriment to $3 C^{\text {pro }}$ activity. It was discovered that the level of TCA required for the deprotection of the substrate in situ would denature the protein, rendering it inactive (data not shown).

\subsection{Cleavage by $3 C^{\text {pro }}$ _Sensitivity and Selectivity Testing}

The activity of the $3 C^{\text {pro }}$ in the presence of the deprotected Boc-AL(Boc)Q(Trt)-AMC 2 was evaluated by monitoring AMC fluorescence. Fluorescence readings were taken on the Infinite M200 PRO plate reader and the parameters were set to an excitation wavelength of $360 \mathrm{~nm}$ and emission wavelength of $455 \mathrm{~nm}$ in order to analyse the release of the fluorophore AMC.

Figure 1 shows the fluorescence data from the $3 C^{\text {pro }}$ cleavage of the Boc-AL(Boc)Q(Trt)-AMC 2, after $10 \mathrm{~min}$ of incubation at $37^{\circ} \mathrm{C}$, one-way ANOVA data and Dunnett's multiple comparison test results. Both of these tests were run on Graphpad 6; the Dunnett's multiple comparison data are 
represented using asterisks $\left(*=p<0.05,{ }^{* * * *}=p<0.0001\right)$. The full details of concentrations and volumes used are in the Supporting Information. The error bars represent the standard deviation of replicates $(n=3)[24]$.

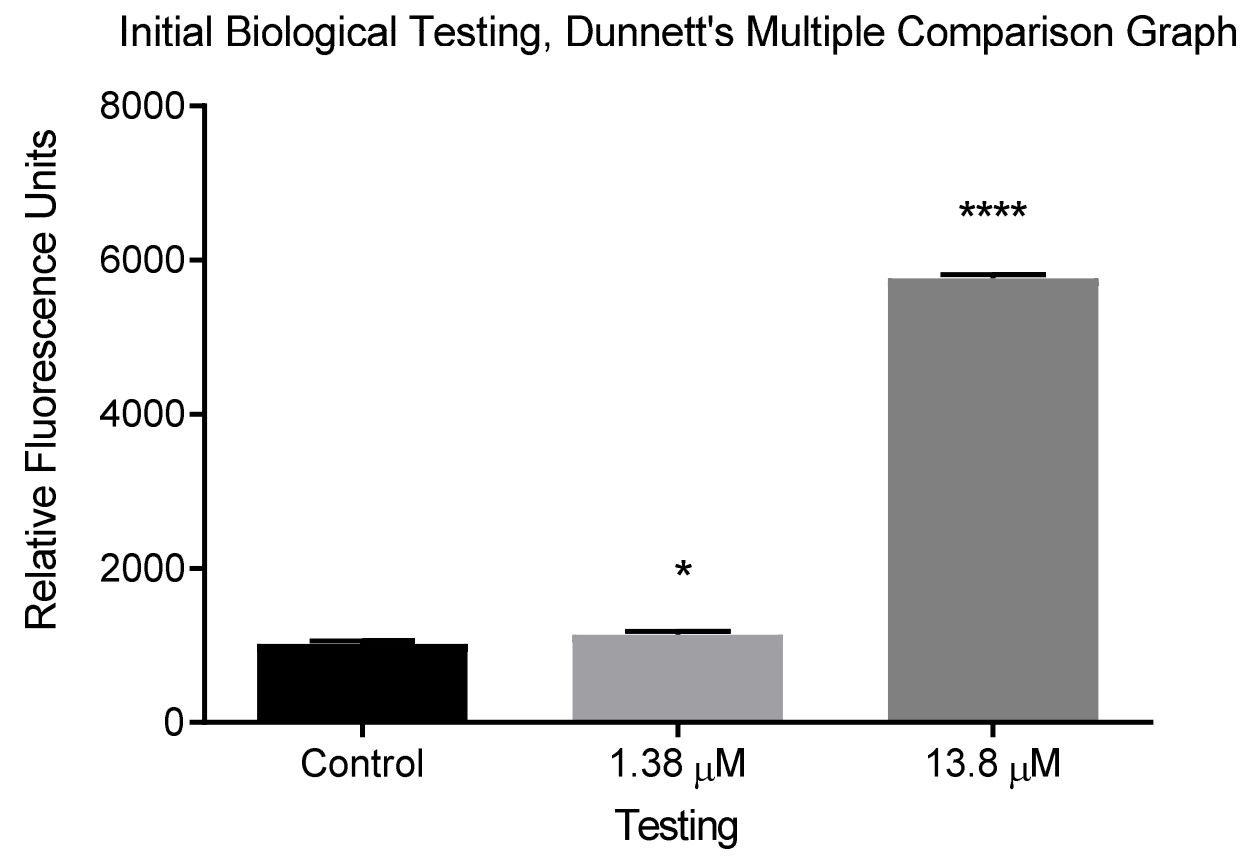

Figure 1. The graph represents the fluorescence data from biological testing after $10 \mathrm{~min}$ of incubation at $37^{\circ} \mathrm{C}$, one-way ANOVA data and Dunnett's multiple comparison test results. Both these tests were run on Graphpad 6; the Dunnett's multiple comparison data are represented using asterisks. ${ }^{*}$ ): control, 2:[E] = $1.38 \mu \mathrm{M}$ and $13.8 \mu \mathrm{M}$, respectively, [S] was controlled in all wells. The full details of concentrations and volumes used given in the appendix; Table 1. The error bars represent the standard deviation of replicates $(n=3)$.

A significant statistical difference was seen using the one-way ANOVA test between the negative control and the testing wells at $13.8 \mu \mathrm{M}$ enzyme $(p<0.0001)$, indicative of a significant change in fluorescence measurements. Further statistical analysis using the Dunnett's multiple comparison test was performed to determine significance from the negative control and each testing well. This is represented in the graph shown in Figure 1. So, from the Dunnett's multiple analysis, we found the higher [E] of $13.8 \mu \mathrm{M}$ and $10 \mathrm{~min}$ incubation caused a more significant change in fluorescence when compared to the ten-fold less [E] of $1.38 \mu \mathrm{M}$ with the negative control wells. Therefore, the higher concentration and volume of $3 C^{\text {pro }}$ was used in further assay tests [23,24].

It is apparent that the fluorescence measurements at time $=0$ were slowly increasing over time, for the stored deprotected substrate solutions [25]. An increase for the [S] at $100 \mu \mathrm{M}$ from $1000 \mathrm{RFU}$ to $2000 \mathrm{RFU}$ was seen after $4 \mathrm{~h}$ in buffer solution (Supporting Information S2). This was thought to be due to the detection probe decomposing, releasing the free fluorophore and highlighting a major problem with stability, an issue faced throughout the synthesis and purification part of the project. Eventually, no change in fluorescence measurements was being recorded, indicating no substrate hydrolysis, as a possible result of the inevitable denaturation of the target enzyme or the decomposition of the unstable probe. Further evidence of cleavage in the presence of our target enzyme has been gained through increased fluorescence, substrate concentrations of $100 \mu \mathrm{M}$ and $150 \mu \mathrm{M}$, this increase in fluorescence was found to be a significant change in comparison to the negative control using the one-way ANOVA statistical method $(p<0.005)$.

To further test the application of the detection probe, a series of experiments were designed to expose the conjugate to other proteases that may be found in a clinical sample taken from livestock 
infected with FMDV. The $3 C^{\text {pro }}$ enzyme is reported to have properties characteristic of cysteine and serine proteases; therefore, the following commonly occurring serine type proteases were selected to test against: chymotrypsin, thrombin and trypsin. To specifically test the amino acid sequence attached to the fluorophore, another enzyme was selected-Tobacco Etch Virus (TEV)—as this is a related cysteine protease with a $\mathrm{Q} / \mathrm{G}$ and $\mathrm{Q} / \mathrm{S}$ selectivity similar to that mentioned for the $3 \mathrm{C}$ protease. This illustrates the importance of the protease when evaluating selectivity. The consensus sequence for TEV is Glu-Asn-Leu-Tyr-Phe-Gln.

From Figure 2, it is apparent that substrate 2 shows selectivity to the $3 C^{\text {pro }}$ enzyme over commonly occurring enzymes in clinical samples. The TEV protease was found to have no significant change in fluorescence measurements recorded in comparison to the negative control using the one-way ANOVA statistical method $(p>0.05)$. Furthermore, the duration of time fluorescence measurement was chosen to be the same length as the assay experiments run with the target enzyme $3 C^{\text {pro }}$ reported earlier as, in the presence of the $3 \mathrm{C}^{\text {pro }}$, fluorescence would be generated more rapidly and, therefore, a delayed increase in fluorescence would be indicative of the breakdown of the conjugate via other routes.

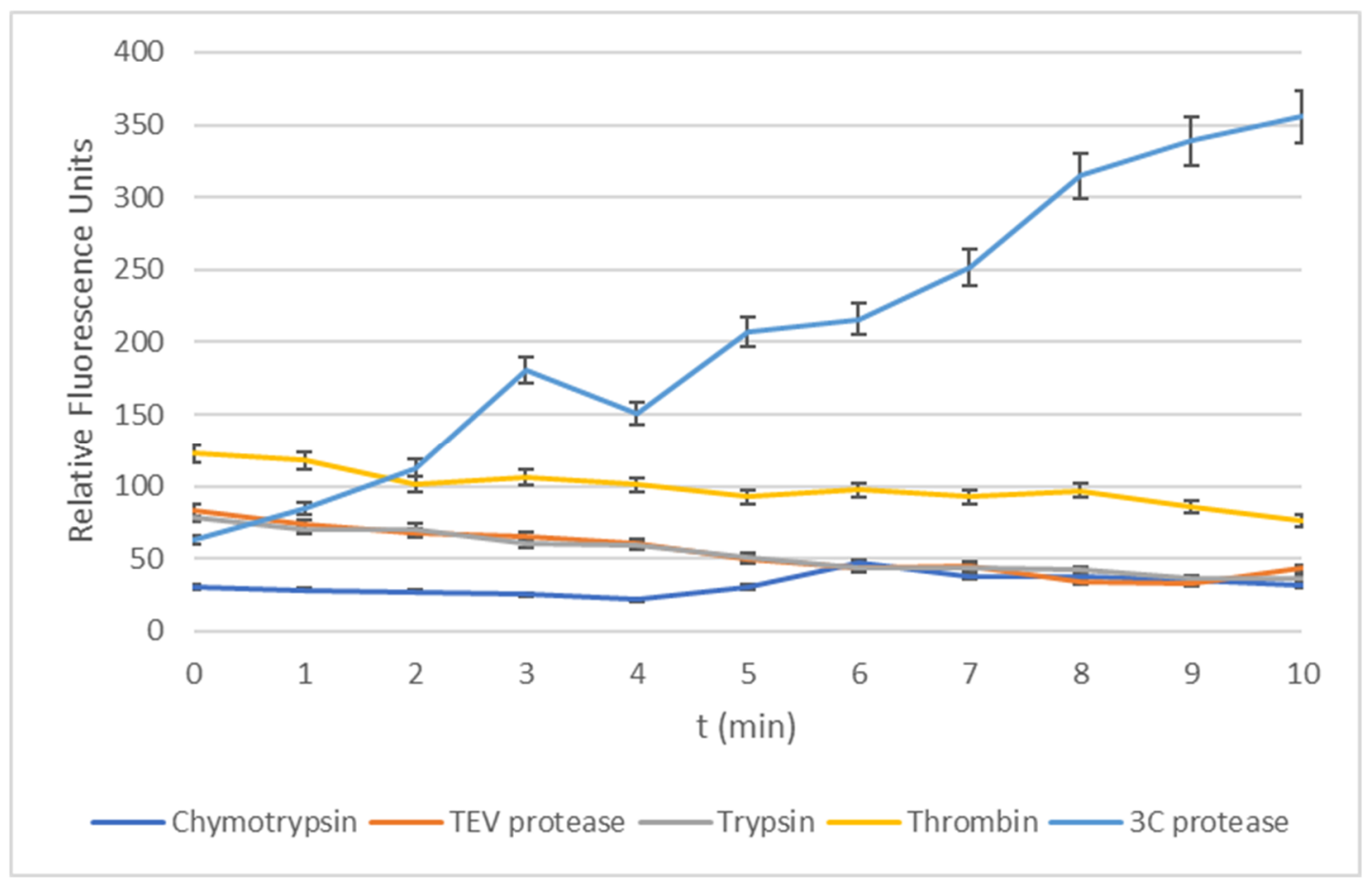

Figure 2. Graph of normalised data between 0-400 to show comparison of all enzymes tested with substrate 2 with $3 C^{\text {pro }}$. Concentrations for enzymes between $13.8 \mu \mathrm{M}-15 \mu \mathrm{M}$ and substrate $100 \mu \mathrm{M}$. Errors bars show $5 \%$ deviation.

\section{Discussion}

From the biochemical testing, the proof of breakdown was gained from our detection probe as a consequence of our target enzyme's activity.

Testing using a range of common proteases shows that the substrate was selectively cleaved by $3 C^{\text {pro }}$, but not by chymotrypsin, thrombin, trypsin and the TEV protease. From the results obtained, it can be concluded that our detection probe is recognised by the $3 C^{\text {pro }}$ and the enzyme is capable of recognising and processing shorter fragments of peptides, previously reported not to be the case [26].

Whilst substrate 2 is stable, upon removal of the trityl group, it appears to decompose in solution. Despite this, we can quite confidently conclude the cleavage of substrate 2, after removal of the trityl groups, was enzyme-assisted and not due to spontaneous decomposition as the measurements recorded from the control wells (enzyme-absent well) remained constant. We also observed the selectivity of 
our probe for $3 \mathrm{C}^{\text {Pro }}$ in comparison with other proteases, suggesting the evolution of fluorescence is enzyme-linked.

However, in solution, the deprotected detection probe was found to have a short shelf-life in comparison to a commercially available BocValProArg-AMC. Although the imminent need for a rapid detection probe has been highlighted in this paper and the recognition of the smaller peptide fragment by $3 C^{\text {pro }}$ has been proven, further work on the stability of the deprotected 2 could potentially provide a more commercially viable detection probe. Immediate immobilization of the BocValProArg-AMC fragment is a possibility.

The AKQ sequence, appears prone to hydrolysis in solution; however, is otherwise stable as a dry solid. From a practical perspective, this may be a limitation, owing to the need to prepare a solution thereof prior to use, however the sensitivity and selectivity of substrate 2 after the removal of the trityl group is compelling and, in this manuscript, we have proved the principle of a selective fluorescent probe, which could be applied as a rapid point-of-decision-making test for FMDV in the field. The authors acknowledge that such an application would demand a stable vehicle for the probe.

\section{Materials and Methods}

\subsection{Synthesis}

NMR was recorded using a Bruker (Coventry, UK) Avance III 400 two channel FT-NMR spectrometer and the Bruiker Avance III 600 three channel FT-NMR spectrometer. ${ }^{1} \mathrm{H}$ NMR spectra were recorded at either 400 or $600 \mathrm{MHz}$ and ${ }^{13} \mathrm{C}$ NMR spectra were recorded at $100 \mathrm{MHz} .{ }^{19} \mathrm{~F} \mathrm{NMR}$ spectra were recorded at $376 \mathrm{MHz}$. Chemical shifts were referenced to the solvent used and noted in the experimental. IR (infrared) was recorded using a Perkin Elmer Spectrum (Buckinghamshire, UK) 100 FT-IR spectrometer. GC/MS was recorded on an Agilent Technologies 5973 mass selective detector, $6890 \mathrm{~N}$ Network GC system. HR-MS and elemental analysis results were obtained via Medac Ltd. (Woking, UK).

TLC analysis was carried out on silica, aluminium oxide, reverse phase silica coated plates and were visualised by a single method or a combination of the following methods: (a) viewing under UV at $254 \mathrm{~nm}$; (b) viewing under UV at $365 \mathrm{~nm}$; (c) exposure to a ninhydrin solution, containing $2 \mathrm{~g}$ of ninhydrin in $60 \mathrm{~mL}$ of ethanol; (d) exposure to a vanillin solution, containing $6 \mathrm{~g}$ of vanillin, $250 \mathrm{~mL}$ of ethanol and $1.5 \mathrm{~mL}$ of $12 \mathrm{M}$ aqueous sulphuric acid.

Preparative TLC was carried out on normal phase silica-based plates; the mobile phase solvent mix is described in ratios in the procedure details. Manual columns were run using normal phase silica of particle size 250-500 $\mu \mathrm{m}$ and 35-60 mesh. Representative NMR and HR-MS data for substrate 2 are in Supporting Information S4.

\subsubsection{Synthesis of $\mathbf{1}$}

Under a nitrogen atmosphere, BocAlaLys(Z)OH (65mg, $0.14 \mathrm{mmol}, 1.5$ eq.), $\mathrm{NH}_{2} \mathrm{GlnAMC}(29 \mathrm{mg}$, $0.96 \mathrm{mmol}, 1$ eq.) and HATU (72 mg, $0.19 \mathrm{mmol}$, 2eq.) were dissolved in $1.5 \mathrm{~mL}$ of anhydrous DMF. To this solution the base DIEA $(5.68 \mathrm{~g}, 80 \mu \mathrm{L}, 5 \mathrm{eq}$.) was added. The resultant yellow solution was left at $50{ }^{\circ} \mathrm{C}$ for a week. The reaction progression was monitored via TLC. The reaction was quenched with $2 \mathrm{~mL}$ of water and extracted with $6 \mathrm{~mL}$ ethyl acetate and further washed with $3 \times 2 \mathrm{~mL}$ saturated lithium chloride solution and dried over $\mathrm{Na}_{2} \mathrm{SO}_{4}$. The reaction mixture was concentrated under reduced pressure and placed on the high vacuum. The crude mixture was purified using preparative TLC $(6.5 \% \mathrm{MeOH}: \mathrm{DCM})(3 \mathrm{mg}, 0.4 \%),{ }_{1}^{1} \mathrm{H}$ NMR $\left(400 \mathrm{MHz}\right.$, methanol- $\left.d_{4}\right) \delta \mathrm{ppm} 1.26-1.35$ (m, $1 \mathrm{H}), 1.41-1.46(\mathrm{~m}, 9 \mathrm{H}), 1.47-1.51(\mathrm{~m}, 1 \mathrm{H}), 1.51-1.52(\mathrm{~m}, 1 \mathrm{H}), 1.52-1.54(\mathrm{~m}, 1 \mathrm{H}), 1.88-1.90(\mathrm{~m}, 1 \mathrm{H})$, 2.43-2.48 (m, $1 \mathrm{H}), 2.69-2.73(\mathrm{~m}, 1 \mathrm{H}), 2.91-2.93(\mathrm{~m}, 1 \mathrm{H}), 3.09-3.16(\mathrm{~m}, 1 \mathrm{H}), 3.34-3.36(\mathrm{~m}, 1 \mathrm{H}), 3.45-3.50$ $(\mathrm{m}, 1 \mathrm{H}), 3.62-3.65(\mathrm{~m}, 1 \mathrm{H}), 5.02-5.07(\mathrm{~m}, 1 \mathrm{H}), 6.21-6.26(\mathrm{~m}, 1 \mathrm{H}), 7.25-7.38(\mathrm{~m}, 1 \mathrm{H}), 7.67-7.76(\mathrm{~m}, 3 \mathrm{H})$, 7.85-7.87 (m, $1 \mathrm{H})$ and 7.90-7.95 (m, $1 \mathrm{H})$. Electrospray, Time of flight, Mass Spectrometry (ES TOF MS) 
found 737.35, requires 736.8 for $\mathrm{C}_{37} \mathrm{H}_{48} \mathrm{~N}_{6} \mathrm{O}_{10}$. The molecular formula verified by elemental analysis: C, 60.01; H, 6.87; N, 11.37; O, 21.70.

\subsubsection{Synthesis of 2}

Under a nitrogen atmosphere, BocAlaLys(Boc)Gln(Trt)OH (50 mg, $0.0634 \mathrm{mmol}, 1$ eq.), AMC (11 mg, $0.0635 \mathrm{mmol}, 1$ eq.) and HATU ( $48 \mathrm{mg}, 0.127 \mathrm{mmol}, 2$ eq.) were dissolved in $5 \mathrm{~mL}$ of anhydrous DMF. To this solution, the base DIEA ( $41 \mathrm{mg}, 55 \mu \mathrm{L}, 5$ eq.) was added. The resultant yellow solution was left at $50{ }^{\circ} \mathrm{C}$ for 3 nights. The reaction progression was monitored via TLC. The reaction was quenched with $10 \mathrm{~mL}$ of water and extracted with $3 \times 10 \mathrm{~mL}$ ethyl acetate and further washed with $3 \times 8 \mathrm{~mL}$ saturated lithium chloride solution and dried over $\mathrm{Na}_{2} \mathrm{SO}_{4}$. The reaction mixture was concentrated under reduced pressure and placed on the high vacuum. The crude mixture was purified using preparative TLC with solvent conditions: $5 \% / 95 \% \mathrm{MeOH}: \mathrm{DCM}$ to give BocAlaLys(Boc)Gln(Trt)AMC as a clear oil $(10 \mathrm{mg}, 15.7 \%) .{ }^{1} \mathrm{H}$ NMR $\left(400 \mathrm{MHz}\right.$, methanol- $\left.d_{4}\right) \delta$ ppm 1.05-1.22 $(\mathrm{m}, 3 \mathrm{H}), 1.23-1.35(\mathrm{~m}, 4 \mathrm{H})$, 1.37-1.53 (m, $18 \mathrm{H}), 2.81(\mathrm{~s}, 1 \mathrm{H}), 2.86(\mathrm{~d}, J=0.75 \mathrm{~Hz}, 1 \mathrm{H}), 2.96-3.08(\mathrm{~m}, 2 \mathrm{H}), 3.69(\mathrm{~d}, J=6.78 \mathrm{~Hz}, 1 \mathrm{H})$, 3.81-4.17 (m, $1 \mathrm{H}), 4.34-4.51(\mathrm{~m}, 1 \mathrm{H}), 4.58-4.67(\mathrm{~m}, 1 \mathrm{H}), 4.68-4.80(\mathrm{~m}, 1 \mathrm{H}), 6.22-6.25(\mathrm{~m}, 1 \mathrm{H}), 7.13-7.33$ $(\mathrm{m}, 15 \mathrm{H}) .{ }^{13} \mathrm{C}$ NMR $\left(100 \mathrm{MHz}\right.$, methanol- $\left.d_{4}\right) \delta \mathrm{ppm}, 16.61,17.31,18.43,19.91,23.10,27.45,28.12$, $28.41,29.93,30.35,30.83,31.31,32.6,33.24,33.33$, 36.46, 37.10, 38.35, 40.23, 49.05, 49.20, 51.56, 54.27, $111.13,117.25,121.35,122.05,127.04,128.18,128.21,133.5$. The mass, confirmed by Electrospray, Time of flight, Mass Spectrometry (ES TOF MS) was found to be $967.4595 \mathrm{C}_{53} \mathrm{H}_{64} \mathrm{~N}_{6} \mathrm{O}_{10} \mathrm{Na}$, requiring 945 for $\mathrm{C}_{53} \mathrm{H}_{64} \mathrm{~N}_{6} \mathrm{O}_{10}$. The molecular formula was verified by elemental analysis: $\mathrm{C}, 67.31 ; \mathrm{H}, 6.87 ; \mathrm{N}, 8.81$; $\mathrm{O}, 16.70$.

\subsection{SDS-PAGE}

$3 \mathrm{C}^{\text {pro }}$ was kindly provided by the Pirbright Institute in Surrey (volume of $100 \mu \mathrm{L}$ at concentration of $13.8 \mu \mathrm{M}$ ). Details of the mutations in the supplied $3 \mathrm{C}^{\text {pro }}$ strain are C95K and C142A. These substitutions are reported to improve solubility and proteolytic activity, respectively. The enzyme was stored at $-80{ }^{\circ} \mathrm{C}$ on arrival and thawed to room temperature for biological assays.

\subsection{DSF}

Following an adapted protocol reported by Niesen et al., pepsin (from porcine stomach mucosa Sigma-Aldrich, Dorset, UK) was diluted to $64 \mu \mathrm{g} / \mathrm{mL}$ in PBS pH 7.4, $0.5 \mathrm{mM}$ EDTA and $5 \times$ Sypro Orange (Oxoid). The fluorescence was measured using an MX3005p qRT-PCR (Stratagene) and the temperature was increased from $25^{\circ} \mathrm{C}$ to $95^{\circ} \mathrm{C}$ at an increment of $1{ }^{\circ} \mathrm{C}$ /minute.

Spectral properties were used for the detection of Sypro Orange: excitation wavelength at $300 / 472 \mathrm{~nm}$ and emission wavelength at $570 \mathrm{~nm}$. Data analysis was completed using software tools obtained from the Structural Genomics Consortium Oxford (ftp://ftp.sgc.ox.ac.uk/pub/biophysics). The raw DSF data were fitted to the Maxwell-Boltzmann distribution in Graphpad Prism 6 to determine the $\mathrm{T}_{\mathrm{M}}$ value.

\subsection{Enzymatic Fluorescence Assay}

All enzyme measurements were performed at room temperature in white round-bottomed plates using an Infinite M200 plate reader (Tecan). To test for the turnover of the substrate by $3 \mathrm{C}$ protease, $100 \mu \mathrm{M}$ of deprotected AlaLysGlnAMC substrate was mixed with $13.8 \mu \mathrm{M}$ or $1.38 \mu \mathrm{M}$ enzyme in a final reaction volume of $100 \mu \mathrm{L}$ PBS 5\% DMSO. Proteolytic cleavage was measured via increased fluorescence intensity (ex 365, em 450). To test for the selectivity of cleavage, all other enzymes were tested under identical experimental conditions.

Supplementary Materials: The following are available online, S1 DSF; S2 Dose Response of 3C ${ }^{\text {pro }}$ to Substrate 2; S3 SDS-PAGE Conditions; S4 Characterisation data for BocAlaLys(Boc)Gln(Trt)AMC, 2; Figure S1. Measuring the effects of TCA on the thermal melt curve of the common enzyme pepsin. The changing percentages of acid are: A (control), 0\% TCA; B, 1\% TCA; C, 0.5\% TCA; D, 0.25\% TCA; Figure S2. Performance testing results represented 
as fluorescence generation in the presence of the target enzyme, $3 \mathrm{C}^{\mathrm{pro}},[\mathrm{E}]=13.8 \mu \mathrm{M}$. The error bars represent the standard deviation of replicates $(n=3)$; Table S1. Biological materials for selectivity testing. All enzymes were stored at -5 to $-20^{\circ} \mathrm{C}$ and thawed to room temperature before running biological assays.

Author Contributions: Conceptualization, A.L.G.; methodology, S.M.; validation, A.L.G. and A.R.; formal analysis, S.M.; investigation, S.M.; resources, A.L.G.; data curation, A.L.G.; writing-original draft preparation, A.L.G.; writing—review and editing, A.R. and S.M.; visualization, S.M.; supervision, A.L.G.; project administration, A.L.G.; All authors have read and agreed to the published version of the manuscript.

Funding: This research received no external funding.

Acknowledgments: The authors are grateful to Veronica Fowler at the Pirbright Institute for the provision of $3 C^{\text {Pro }}$ and for useful conversations. We are also grateful to Kingston University for providing SM with a fully funded PhD studentship and to Jean-Marie Peron for excellent NMR support.

Conflicts of Interest: The authors declare no conflict of interest.

\section{References}

1. Birtley, J.R.; Knox, S.R.; Jaulent, A.M.; Brick, P.; Leatherbarrow, R.J.; Currey, S. New insights into catalytic mechanism and cleavage specificity. J. Biol. Chem. 2005, 280, 11520-11527. [CrossRef] [PubMed]

2. Kristensen, T.; Normann, P.; Gullberg, M.; Fahnoe, U.; Polacek, C.; Rasmussen, T.B.; Belsham, G.J. Determinants of the VP1/2A junction cleavage by the 3C protease in foot-and-mouth disease virus-infected cells. J. Gen. Virol. 2017, 98, 385-395. [CrossRef]

3. Curry, S.; Roqué-Rosell, N.; Sweeney, T.R.; Zunszain, P.A.; Leatherbarrow, R.J. Structural analysis of foot-and-mouth disease virus 3C protease: A viable target for antiviral drugs? Biochem. Soc. Trans. 2007, 35, 594-598. [CrossRef] [PubMed]

4. Zahur, A.B.; Irshad, H.; Hussain, M.; Anjum, R.; Khan, M.G. Transboundary animal diseases in Pakistan. Zoonoses Public Health 2006, 53, 19-22. [CrossRef]

5. Knowles, N.J.; He, J.; Shang, Y.; Wadsworth, J.; Valdazo-González, B.; Onosato, H.; Fukai, K.; Morioka, K.; Yoshida, K.; Cho, I.-S.; et al. Southeast asian foot-and-mouth disease viruses in eastern asia. Emerg. Infect. Dis. 2012, 18, 499-501. [CrossRef]

6. Cottam, E.M.; Haydon, D.T.; Paton, D.J.; Gloster, J.; Wilesmith, J.W.; Ferris, N.P.; Hutchings, G.H.; King, D.P. Molecular epidemiology of the foot-and-mouth disease virus outbreak in the United Kingdom in 2001. J. Virol. 2006, 80, 11274-11282. [CrossRef] [PubMed]

7. Madi, M.; Hamilton, A.; Squirrell, D.; Mioulet, V.; Evans, P.; Lee, M.; King, D.P. Rapid detection of foot-and-mouth disease virus using a field-portable nucleic acid extraction and real-time PCR amplification platform. Vet. J. 2011, 193, 67-72. [CrossRef]

8. Notomi, T.; Okayama, H.; Masubuchi, H.; Yonekawa, T.; Watanabe, K.; Amino, N.; Hase, T. Loop-mediated isothermal amplification of DNA. Nucleic Acids Res. 2000, 28, E63. [CrossRef]

9. Sajid, M.; Kawde, A.N.; Daud, M. Designs, formats and applications of lateral flow assay: A literature review. J. Saudi Chem. Soc. 2016, 82, 286. [CrossRef]

10. Medina, G.N.; Segundo, F.D.-S.; Stenfeldt, C.; Arzt, J.; de los Santos, T. The different tactics of foot-and-mouth disease virus to evade innate immunity. Front. Microbiol. 2018, 9. [CrossRef]

11. Howson, E.L.A.; Armson, B.; Madi, M.; Kasanga, C.J.; Kandusi, S.; Sallu, R.; Chepkwony, E.; Siddle, A.; Martin, P.; Wood, J.; et al. Evaluation of two lyophilized molecular assays to rapidly detect foot-and-mouth disease virus directly from clinical samples in field settings. Transbound. Emerg. Dis. 2017, 64, 861-871. [CrossRef] [PubMed]

12. Shinowara, G.Y. Human thrombin and fibrinogen the kinetics of their interaction and the preparation of the enzyme. Biochim. Biophys. Acta (BBA)-Enzymol. Biol. Oxid. 1966, 113, 359-374. [CrossRef]

13. Wang, D.; Fang, L.; Chen, Q.; Bi, J.; Cao, L.; Luo, R.; Chen, H.; Xiao, S. Foot and mouth disease virus leader proteinase inhibits dsRNA-induced RANTES transcription in PK-15 cells. Virus Genes 2011, 42, 388-393. [CrossRef] [PubMed]

14. Belsham, G.J.; McInerney, G.M.; Ross-Smith, N. Foot-and-mouth disease virus 3C protease induces cleavage of translation initiation factors EIF4A and EIF4G within infected cells. J. Virol. 2000, 74, 272-280. [CrossRef]

15. Falk, M.M.; Grigera, P.R.; Bergmann, I.E.; Zibert, A.; Multhaup, G.; Beck, E. Foot-and-mouth disease virus protease 3C induces specific proteolytic cleavage of host cell histone H3. J. Virol. 1990, 64, 748-756. [CrossRef] 
16. Wang, D.; Fang, L.; Li, K.; Zhong, H.; Fan, J.; Ouyang, C.; Zhang, H.; Duan, E.; Luo, R.; Zhang, Z.; et al. Foot-and-mouth disease virus $3 C$ protease cleaves NEMO to impair innate immune signaling. J. Virol. 2012, 86, 9311-9322. [CrossRef]

17. Lawrence, P.; Schafer, E.A.; Rieder, E. The nuclear protein Sam68 is cleaved by the FMDV 3C protease redistributing Sam68 to the cytoplasm during FMDV infection of host cells. Virology 2012, 425, 40-52. [CrossRef]

18. Rabbani, G.; Ahmad, E.; Khan, M.V.; Ashraf, M.T.; Bhat, R.; Khan, R.H. Impact of structural stability of cold adapted candida antarctica lipase B (CaLB): In relation to PH, chemical and thermal denaturation. RSC Adv. 2015, 5, 20115-20131. [CrossRef]

19. Rabbani, G.; Ahmad, E.; Zaidi, N.; Fatima, S.; Khan, R.H. PH-induced molten globule state of rhizopus niveus lipase is more resistant against thermal and chemical denaturation than its native state. Cell Biochem. Biophys. 2012, 62, 487-499. [CrossRef]

20. Roqué Rosell, N.R.; Mokhlesi, L.; Milton, N.E.; Sweeney, T.R.; Zunszain, P.A.; Curry, S.; Leatherbarrow, R.J. Design and synthesis of irreversible inhibitors of foot-and-mouth disease virus $3 \mathrm{C}$ protease. Bioorg. Med. Chem. Lett. 2014, 24, 490-494. [CrossRef]

21. Jaulent, A.M.; Fahy, A.S.; Knox, S.R.; Birtley, J.R.; Roqué-Rosell, N.; Curry, S.; Leatherbarrow, R.J. A continuous assay for foot-and-mouth disease virus 3C protease activity. Anal. Biochem. 2007, 368, 130-137. [CrossRef] [PubMed]

22. Niesen, F.H.; Berglund, H.; Vedadi, M. The use of differential scanning fluorimetry to detect ligand interactions that promote protein stability. Nat. Protoc. 2007, 2, 2212-2221. [CrossRef] [PubMed]

23. Birtley, J.R.; Curry, S. Crystallization of foot-and-mouth disease virus $3 C$ protease: Surface mutagenesis and a novel crystal-optimization strategy. Acta Cryst. D 2005, 61, 646-650. [CrossRef] [PubMed]

24. Sweeney, T.; Roqué Rosell, N.; Birtley, J.; Leatherbarrow, R.; Curry, S. Structural and mutagenic analysis of foot-and-mouth disease virus 3 c protease reveals the role of the -ribbon in proteolysis. J. Virol. 2007, 81, 115-124. [CrossRef]

25. Rabbani, G.; Ahmad, E.; Zaidi, N.; Khan, R.H. PH-dependent conformational transitions in conalbumin (ovotransferrin), a metalloproteinase from hen egg white. Cell Biochem. Biophys. 2011, 61, 551-560. [CrossRef]

26. Knight-Jones, T.J.D.; Robinson, L.; Charleston, B.; Rodriguez, L.L.; Gay, C.G.; Sumption, K.J.; Vosloo, W. Global Foot-and-mouth disease research update and gap analysis: 1 -Overview of global status and research needs. Transbound. Emerg. Dis. 2016, 63, 3-13. [CrossRef] 